\title{
Different types of smooth muscle antibodies in chronic active hepatitis and primary biliary cirrhosis: their diagnostic and prognostic significance
}

\author{
P KURKI,* A MIETTINEN, E LINDER, P PIKKARAINEN, M VUORISTO, AND \\ M P SALASPURO \\ From the Department of Bacteriology and Immunology, University of Helsinki, and Gastroenterological Unit \\ of the Second Department of Medicine, University of Helsinki, Helsinki, Finland
}

SUMMARY The diagnostic and prognostic significance of the different types of serum smooth muscle antibodies (SMA) were investigated in sera of 24 patients with chronic active hepatitis $(\mathrm{CAH})$ and 15 patients with primary biliary cirrhosis (PBC). SMA of IgG class were found in $92 \%$ of sera from patients with CAH but in only $20 \%$ of sera from PBC patients, whereas the incidence of IgM-SMA was higher in PBC (67\%) than in CAH (38\%). All six patients with the atypical cholestatic form of CAH had SMA of IgM class, whereas other CAH patients had SMA of mainly IgG class. SMA reacting with rabbit liver (bile canaliculus antibodies, BCA) and with rat glomeruli (glomerulus antibodies) were of anti-actin specificity and were more common in CAH than in PBC. Organ specific BCA or glomerulus antibodies were not found. Anti-actin antibodies were detected in the majority of the investigated sera by an immunoenzymatic anti-aciin assay. The results suggest that the determination of SMA titres with heavy chain specific antisera may help in the assessment of diagnosis and prognosis of chronic hepatitis.

Chronic active hepatitis (CAH) and primary biliary cirrhosis (PBC) are characterised by the presence of high titres of non-organ specific autoantibodies; mitochondrial antibodies (AMA) in PBC and antinuclear antibodies (ANA) and smooth muscle antibodies (SMA) in CAH. These autoantibodies have differential diagnostic importance ${ }^{1}$ but this is disturbed by the considerable overlap between the serological findings in CAH and PBC. AMA occur in $83-100 \%$ of cases with PBC and in $11-35 \%$ of cases with CAH. SMA are found in $61-86 \%$ of patients with CAH and in $32-49 \%$ of patients with PBC. ${ }^{2-8}$ Antinuclear antibodies are frequently found in both diseases. Some authors have described glomerulus antibodies ${ }^{9}$ and bile canaliculus antibodies $^{1011}$ in CAH and PBC, and a relationship to SMA has been proposed. ${ }^{12-14}$

The determination of different types of AMA may have diagnostic significance. ${ }^{15}$ There are also several types of smooth muscle antibodies. ${ }^{17}$ SMA in

\footnotetext{
*Address for correspondence: Pekka Kurki, MD, Clinical Immunology Section, Department of Bacteriology and Immunology, University of Helsinki, Haartmaninkatu 3, SF-00290 Helsinki 29, Finland.

Received for publication 27 May 1980.
}

chronic active hepatitis are claimed to be of antiactin specificity ${ }^{18}{ }^{19}$ but the specificity of SMA in primary biliary cirrhosis is not known.

The aim of this study was to investigate the specificity and diagnostic significance of the different types of SMA in primary biliary cirrhosis and chronic active hepatitis. For that purpose we determined the immunoglobulin class and the immunofluorescence staining patterns of SMA. Anti-actin antibodies were assayed by a solid phase immunoenzymatic technique, anti-actin-ELISA. ${ }^{20}$

\section{Methods}

\section{PATIENTS}

Stored sera $\left(-20^{\circ} \mathrm{C}\right)$ from 24 patients with chronic active hepatitis $(\mathrm{CAH})$ and 15 patients with primary biliary cirrhosis (PBC) were examined. All sera were $\mathrm{HB}_{\mathrm{S}} \mathrm{AG}$-negative by complement fixation and radioimmunoassay (Austria II, Abbot Laboratories, Chicago, Illinois). Patients with $\mathrm{CAH}$ had mean age of 36 years (range 21-69 years) and fe$\mathrm{male} / \mathrm{male}$ ratio of $16 / 8$. The diagnosis was based on accepted histological criteria. ${ }^{21}$ Six patients had an atypical form of CAH characterised by bio- 
chemical signs of cholestasis and a poor response to customary immunosuppressive treatment. ${ }^{22} 23$ All patients with PBC were females and had a mean age of 53 years (range 32-69 years). The diagnosis was based on typical clinical, biochemical, immunological, and histological findings as published in detail before 22 and the diagnostic criteria were similar to those reported by Sherlock and Scheuer. ${ }^{24}$ The presence of smooth muscle antibodies was not included in the diagnostic criteria of either disease. At the time when serum samples were drawn, seven patients with $\mathrm{CAH}$ were treated with prednisone and azathioprine, four patients with prednisone, and four patients with azathioprine. One patient with PBC was treated with azathioprine and two with a combination of azathioprine and prednisone.

\section{TISSUE ANTIBODIES}

Tissue antibodies were detected by the indirect immunofluorescence (IFL) technique. Smooth muscle antibodies (SMA), antinuclear antibodies (ANA), mitochondrial antibodies (AMA), and antibodies reacting with glomeruli were assayed by indirect immunofluorescence using unfixed cryostat sections of rat kidney and stomach as substrate and bile canaliculus antibodies using rabbit liver as substrate. ${ }^{25}$ The diagnostic criteria for SMA were: definite fluorescence in the muscularis mucosae and interglandular smooth muscle fibres of rat stomach and in rat renal arteriolar walls. FITC labelled sheep anti-human immunoglobulin (Lot SH 074510, National Bacteriological Laboratory, Stockholm, Sweden) had a molar $F / P$ ratio 3.5 and FITC labelled heavy chain specific antisera to human IgG (Lot 89361), IgA (Lot 89473), and IgM (Lot 89374, Meloy Laboratories, Springfield, Virginia) had molar $\mathrm{F} / \mathrm{P}$ ratios of $2 \cdot 9,2 \cdot 3$, and $3 \cdot 0$, respectively. Bile canaliculi were visualised by the histochemical ATP :ase staining. ${ }^{26}$

\section{ABSORPTION AND ELUTION EXPERIMENTS}

Rheumatoid factors were determined by slide agglutination (Latex-RF reagent, Behringwerke, Marburg, GFR). Absorption of rheumatoid factors was performed with $20 \mathrm{mg}$ aggregated (30 minutes at $63^{\circ} \mathrm{C}$ ) human IgG (Kabi, Stockholm, Sweden)/
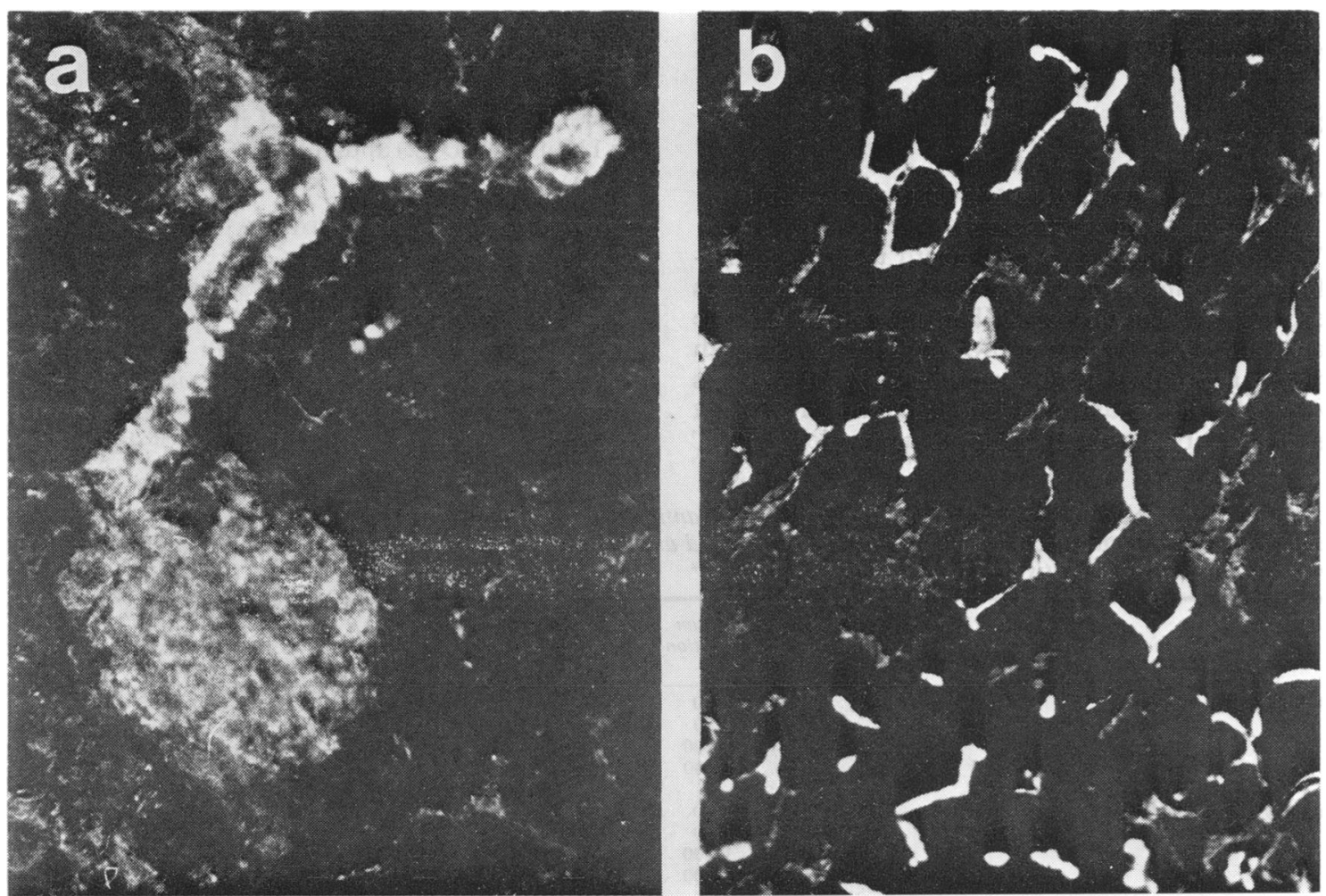

Fig. 1 Reaction of smooth muscle antibodies with cryostat sections of rat kidney (a) and rabbit liver (b) by indirect immunofluorescence. Note the immunofluorescence staining of arteriolar walls and glomerulus (a) and the periphery of hepatocytes $(b) . \times 500$. 
ml serum. SMA were immunologically purified by eluting the antibodies from cryostat sections of human uterus by low pH. A serum pool was made from 10 SMA positive sera. It contained also antibodies reacting with glomeruli and nuclei in rat kidney and bile canaliculi in rabbit liver and with mouse parietal cells.

The serum pool was allowed to react with cryostat sections of human uterus for $\mathbf{3 0}$ minutes. The sections were then washed twice with phosphate buffered saline, $\mathrm{pH} \mathbf{7 \cdot 2}$, for 10 minutes and the bound antibodies were eluted by $0.1 \mathrm{M}$ citrate buffer, $\mathrm{pH} 2 \cdot 8$, for five to 30 minutes. The eluate was then neutralised by $1 \mathrm{M} \mathrm{NaOH}$ and tested for tissue antibodies.

\section{ANTI-ACTIN ANTIBODIES}

Anti-actin antibodies were determined by enzymelinked immunosorbent assay (ELISA) as described earlier. ${ }^{20}$ Disposable polystyrene tubes were coated with purified actin $(0.02 \mathrm{mg} / \mathrm{ml}$ buffer $)$. Patient sera were diluted $1: 100$ and the anti-actin antibodies were detected using immunologically purified alkaline phosphatase-coupled goat anti-human IgG. Actin was prepared from bovine skeletal muscle as described earlier. ${ }^{17}$

\section{Results}

\section{INCIDENCE, TITRE, AND IMMUNOGLOBULIN}

\section{CLASS OF TISSUE ANTIBODIES}

The incidence and titre of smooth muscle, antinuclear and mitochondrial antibodies and antibodies reacting with rat glomeruli (Fig. 1a) and rabbit bile canaliculi (Fig. 1b) are shown in Table 1. Smooth muscle antibodies were found in $88 \%$ of patients with CAH at serum dilution $1: 10$ and in $54 \%$ at serum dilution 1:200 using a polyvalent FITC labelled anti-human immunoglobulin. Seventy-five per cent of patients with PBC had SMA in their serum at dilution $1: 10$ and only one patient $(7 \%)$ at serum dilution 1:200 $(\mathrm{P}<0.01$, when compared with $\mathrm{CAH}$ ). All sera containing glomerulus and bile canaliculus antibodies were also SMA positive. The immunoglobulin class of SMA, ANA and AMA is seen in Table 2, which shows that SMA in chronic active hepatitis were mainly of the IgG class, whereas patients with primary biliary cirrhosis had more IgM-SMA (Fig. 2). SMA of IgA class were found in three patients with CAH. Twelve out of the 24 patients with $\mathrm{CAH}$ had rheumatoid factors at the titre 1:4; two had titres exceeding 1:32. Thirteen out of the 15 patients with PBC had rheumatoid factors at the titre $1: 4$ and three patients had titres exceeding $1: 32$. Neutralisation of the rheumatoid factors with aggregated IgG did not change the titres of tissue antibodies of IgM class.

\section{ANTI-ACTIN ANTIBODIES}

In the anti-actin ELISA test 21 out of the 24 patients with chronic active hepatitis $(88 \%)$ and 10 out of the 15 patients with primary biliary cirrhosis $(67 \%)$ had values exceeding the mean $+2 \mathrm{SD}$ (71 Units, Ref. 20) of the 157 control sera from students and blood donors. The mean anti-actin-ELISA value in CAH was 113 units (SD 42) and in PBC 120 units (SD 91).

\section{SMOOTH MUSCLE ANTIBODIES AND THE \\ CLINICAL COURSE OF CAH}

Six patients with CAH of atypical cholestatic form and poor response to treatment ${ }^{22}$ were compared with the other 18 patients (Fig. 3). SMA of IgM class were found in all six patients in the former group but in only three patients in the latter group. In this group all patients had SMA of IgG class.

Table 1 Incidence of smooth muscle antibodies (SMA), antibodies to rat glomeruli $(G A)$ and rabbit bile canaliculi $(B C A)$, antimitochondrial antibodies $(A M A)$ and antinuclear antibodies $(A N A)$ in sera from patients with chronic active hepatitis and primary biliary cirrhosis*

\begin{tabular}{|c|c|c|c|c|c|c|c|}
\hline \multirow[t]{2}{*}{ Diagnosis } & \multirow{2}{*}{$\begin{array}{l}\text { Number } \\
\text { of sera }\end{array}$} & \multirow{2}{*}{$\begin{array}{l}\text { Serum } \\
\text { dilution }\end{array}$} & \multirow{2}{*}{$\begin{array}{l}S M A \\
(\%)\end{array}$} & \multicolumn{4}{|c|}{ Incidence $\%$} \\
\hline & & & & $\overline{G A}$ & $B C A$ & $A M A$ & $A N A$ \\
\hline Chronic active hepatitis & 24 & $\begin{array}{l}1: 10 \\
1: 50 \\
1: 200 \\
1: 800\end{array}$ & $\begin{array}{l}88 \\
67 \\
54 \\
29\end{array}$ & $\begin{array}{l}63 \\
46 \\
29 \\
13\end{array}$ & $\begin{array}{r}50 \\
42 \\
29 \\
8\end{array}$ & $\begin{array}{l}21 \\
17 \\
13 \\
13\end{array}$ & $\begin{array}{l}71 \\
71 \\
21 \\
13\end{array}$ \\
\hline Primary biliary cirrhosis & 15 & $\begin{array}{l}1: 10 \\
1: 50 \\
1: 200 \\
1: 800\end{array}$ & $\begin{array}{r}73 \\
33 \\
7 \\
-\end{array}$ & $\begin{array}{l}27 \\
20 \\
- \\
-\end{array}$ & $\begin{array}{r}27 \\
20 \\
7 \\
-\end{array}$ & $\begin{array}{l}100 \dagger \\
100 \\
100 \\
93\end{array}$ & $\begin{array}{l}47 \\
40 \\
27 \\
13\end{array}$ \\
\hline
\end{tabular}

Antibodies were assayed by indirect immunofluorescence technique using rat stomach and kidney and rabbit liver as substrate. A sheep antihuman immunoglobulin conjugate was used.

$+\mathrm{P}<0.001$. 
Table 2 Smooth muscle $(S M A)$, antinuclear $(A N A)$, and antimitochondrial $(A M A)$ antibodies determined by heavy chain specific antisera to human $\operatorname{IgG}, \operatorname{Ig} A$ and $\operatorname{Ig} M^{*}$

\begin{tabular}{|c|c|c|c|c|c|c|c|c|c|c|}
\hline \multirow[t]{3}{*}{ Diagnosis } & \multirow{3}{*}{$\begin{array}{l}\text { Number } \\
\text { of sera }\end{array}$} & \multicolumn{9}{|c|}{ Percentage of positive sera } \\
\hline & & \multicolumn{3}{|c|}{$S M A$} & \multicolumn{3}{|l|}{$A N A$} & \multicolumn{3}{|c|}{$A M A$} \\
\hline & & IgG & $\operatorname{IgA}$ & $\operatorname{IgM}$ & $I g G$ & $\operatorname{IgA}$ & $I g M$ & $I g G$ & $\operatorname{Ig} A$ & $\operatorname{Ig} M$ \\
\hline Chronic active hepatitis & 24 & $92+$ & 13 & 38 & 54 & 13 & 33 & 21 & - & 8 \\
\hline Primary biliary cirrhosis & 15 & 20 & - & 67 & 40 & - & 47 & $100 \dagger$ & $40 \ddagger$ & $60 \ddagger$ \\
\hline
\end{tabular}

*SMA, ANA and AMA were assayed by indirect immunofluorescence at patient serum dilution 1:10 using unfixed cryostat sections of rat stomach and kidney as substrate.

$\nmid \mathbf{P}<0.001$. $\$ \mathbf{P}<0.01$.

Three out of the six patients with atypical $\mathrm{CAH}$ and one of the other patients had mitochondrial antibodies. The anti-actin-ELISA revealed a mean value of 79 Units (range 47-103) in the group of patient with atypical CAH and 119 Units (range 56-209) in the other group of CAH.

\section{SPECIFICITY OF GLOMERULUS AND BILE}

CANALICULUS ANTIBODIES

The specificity of BCA and glomerulus antibodies (Fig. 1a) was studied by absorption with purified skeletal muscle actin in 16 sera containing both

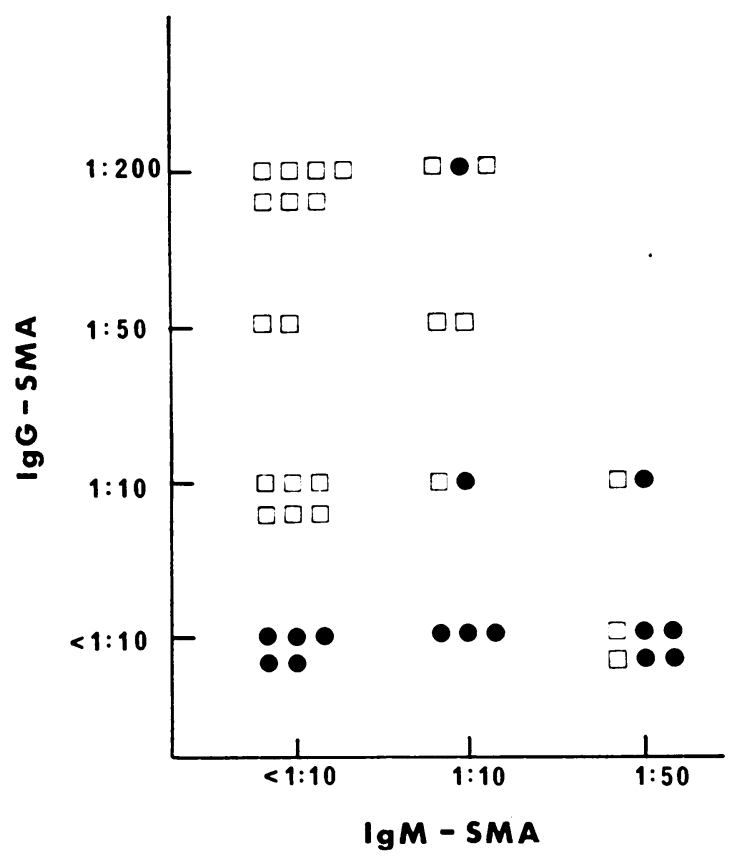

Fig. 2 The titres of smooth muscle antibodies of IgG and IgM class in sera from patients with chronic active hepatitis (squares) and primary biliary cirrhosis (circles). smooth muscle antibodies and antibodies reacting with bile canaliculi and glomeruli. A typical bile canalicular staining pattern is seen in Fig. 1b. The staining pattern of BCA positive sera corresponded to the histochemical ATPase staining of bile canaliculi. In all 16 sera both SMA and antibodies to glomeruli and bile canaliculi could be neutralised by $100 \mathrm{mg}$ skeletal muscle actin/ml undiluted serum. The organ specificity of BCA and glomerulus antibodies was studied also in elution experiments.

The serum pool consisting of 10 SMA positive sera was allowed to react with unfixed cryostat

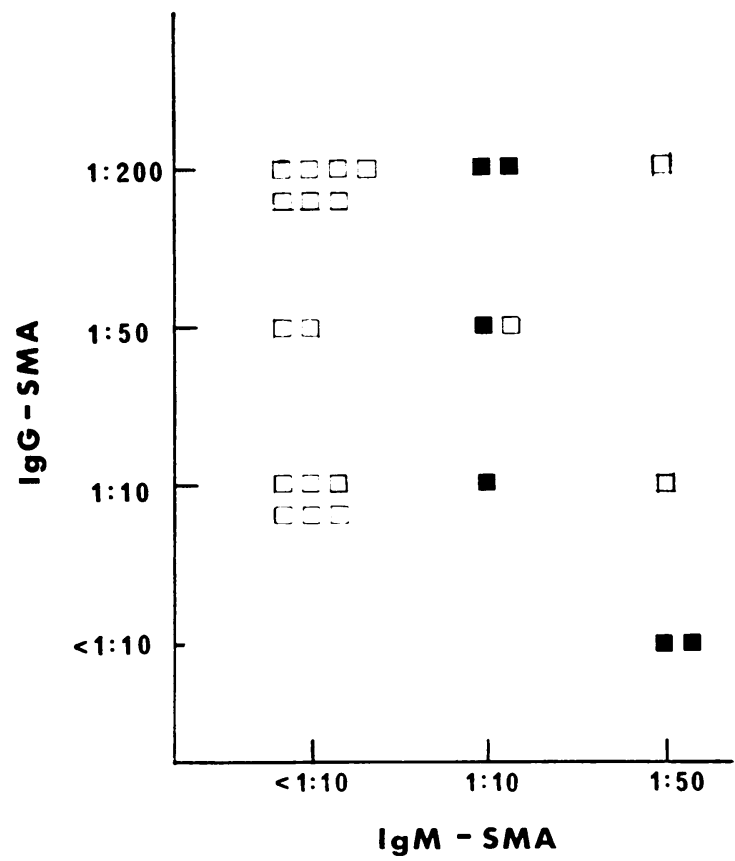

Fig. 3 The titres of smooth muscle antibodies of IgG and IgM class in sera from patients with chronic active hepatitis $(C A H)$. Patients with the atypical cholestatic form of $\mathrm{CAH}$ (filled squares) are compared with other CAH patients (open squares). 
sections of human uterus and the antibodies were eluted with citrate buffer for five minutes. The neutralised eluate reacted with smooth muscle and with glomeruli in rat kidney and with bile canaliculi in rabbit liver. When the elution time was prolonged to 30 minutes also antinuclear activity was seen. This finding was not due to non-specific binding of immunoglobulins, as human antibodies to mouse parietal cells could not be eluted in the same way.

\section{Discussion}

The present study confirms the high incidence of SMA in chronic active hepatitis (CAH) and primary biliary cirrhosis (PBC). There are several types of $\mathrm{CAH}$. CAH patients in this material had either the 'autoimmune' or the 'cryptogenic' type of the disease. Patients with CAH had higher titres and a higher incidence of smooth muscle antibodies (SMA) of IgG class. In our material SMA titres exceeding 1:50 were rarely seen in PBC. This is in agreement with earlier reports. ${ }^{27}{ }^{28} \mathrm{~A}$ new finding was that $67 \%$ of patients with PBC had SMA of IgM class compared with $38 \%$ in sera from patients with CAH. This marked difference was not seen in antinuclear antibodies, which occurred in about one half of the sera.

The incidence of glomerulus antibodies is known to be higher in patients with CAH than in patients with viral hepatitis, cryptogenic cirrhosis, and chronic persistent hepatitis. ${ }^{129}{ }^{29}$ The present results and our previous investigations show that the incidence of glomerulus antibodies in CAH is higher than in PBC or in patients with malignant disease. ${ }^{25}$ An increased incidence of bile canalicular antibodies (BCA) has been described in patients with viral hepatitis $(38 \%)$, PBC $(35 \%),{ }^{11}$ and CAH $(66 \%))^{10}$ Our results support the earlier suggestion $^{30}$ that the BCA assay can be useful in the diagnosis of chronic active hepatitis. Organ specificity of glomerulus antibodies and BCA has been proposed based on absorption studies and on the finding of these antibodies without other antibody activities..$^{91}$ In our material the glomerular and bile canalicular fluorescence was always associated with SMA. The presence of organ specific glomerulus antibodies and BCA was not ruled out but our findings indicate that these antibodies cannot be determined by the standard IFL test without actin absorption. However, the recording of glomerular and bile canalicular staining helps to distinguish SMA of anti-actin specificity from 'non-actin' SMA.

SMA in CAH have previously been shown to be of anti-actin specificity. ${ }^{18}{ }^{19}$ Our results in the IFL test and in the ELISA assay indicate that most patients with CAH and PBC have anti-actin antibodies. The anti-actin ELISA seems to give more positive results than the IFL-assay. This may be due to the fact that the ELISA test measures also antibodies to denatured actin. ${ }^{20}$ Anti-actin antibodies have been found in some patients with nonhepatic diseases, ${ }^{1732-34}$ but the majority of SMA in these diseases seem to have other specificities. ${ }^{35} 17$

Some patients with chronic active hepatitis are resistant to the customary immunosuppressive treatment. ${ }^{232236}$ These cases are characterised by cholestatic features: high serum levels of alkaline phosphatase, gammaglutamyltranspeptidase, and of bile acids. ${ }^{22}$ Hepatic copper levels are increased and an intracellular copper binding protein can be demonstrated histologically by orcein staining. ${ }^{37}$

With early administration of high doses of immunosuppressive drugs the progression of the disease may be prevented. ${ }^{23} \mathrm{~A}$ distinct subclass of mitochondrial antibodies has been shown to occur in patients with the cholestatic form of $\mathrm{CAH}^{15}$ The prognostic significance of other tissue antibodies is controversial. ${ }^{23} 36$ In this material all patients with the cholestatic form of CAH had SMA of IgM class which were rare in other CAH patients (Fig. 3). The determination of IgM-SMA may thus help to recognise cases which need higher doses of immunosuppressive drugs. Interestingly, the determination of SMA with heavy chain specific anti-immunoglobulin antisera was previously shown to be useful in the assessment of prognosis in $\mathrm{HB}_{\mathbf{S}} \mathrm{AG}$-positive viral hepatitis. ${ }^{38} 39$ Mitochondrial antibodies also seemed to be associated with atypical CAH, although the different subtypes of AMA were not determined.

It can be concluded that the titration and more defined classification of the tissue antibodies, notably smooth muscle antibodies and mitochondrial antibodies, may give important information for the assessment of the diagnosis and prognosis of chronic hepatitis. However, there is considerable overlap in the serological findings of $\mathrm{CAH}$ and PBC. This is in agreement with the knowledge that these diseases sometimes have common clinical, biochemical, and histological features. ${ }^{1}$

We are grateful to Ms Kirsti Kemppainen, Ms Ritva Majuri, Ms Tuula Moisio, and the staff of the Gastroenterological Unit of the Second Department of Medicine for technical assistance. This work was supported by grants from the Finnish Culture Foundation, Finnish Foundation for Alcohol Studies, and the Finnish Foundation for Cancer Research. 


\section{References}

${ }^{1}$ Sherlock S. Chronic hepatitis. Gut 1974; 15: 581-97.

${ }^{2}$ Doniach D. Autoimmunity in liver diseases. Progr Clin Immunol 1972; 1: 45-70.

${ }^{3}$ Dudley FJ, O'Shea MF, Ajdukiewicz A, Sherlock S. Serum autoantibodies and immunoglobulins in hepatitis-associated antigen (HAA)-positive and -negative liver disease. Gut 1973; 14: 360-64.

${ }^{4}$ Findor J, Bruch Igartua E, Alonso A, Domecq R, Bozzola C. Australian antigen and circulating antibodies in chronic hepatitis. Acta Hepato-Gastroenterol 1973; 20: 98-102.

${ }^{5}$ Galbraith RM, Smith M, MacKenzie RM, Tee DE, Doniach D, Williams $\mathbf{R}$. High prevalence of seroimmunologic abnormalities in relatives of patients with active chronic hepatitis or primary biliary cirrhosis. N Engl J Med 1974; 290: 63-9.

${ }^{6}$ Gitnick GL. Summerskill WHJ, Soloway RD, Ritman S, Schoenfield LJ. Anticomplementary hepatitis . B antigen. Arch Intern Med 1973; 213: 502-5.

${ }^{7}$ Husby G, Skrede S, Blomhoff JP, Jakobsen CD, Berg K, Gjone E. Serum immunoglobulins and organ non-specific antibodies in disease of the liver. Scand $J$ Gastroenterol 1977; 12: 297-304.

${ }^{8}$ Klatskin G, Kantor FS. Mitochondrial antibody in primary biliary cirrhosis and other diseases. Ann Intern Med 1972; 77: 533-41.

${ }^{9}$ Levy RL, Hong R. Anti-glomerular antibody in chronic active and chronic persistent hepatitis. $J$ Pediatr 1974; 85: $155-8$.

${ }^{10}$ Diederichsen $\mathrm{H}$. Hetero-antibody against bile canaliculi in patients with chronic, clinically active hepatitis. Acta Med Scand 1969; 186: 299-302.

${ }^{11}$ MacSween RNM, Armstrong EM, Gray KG, Mason M. Bile canalicular antibody in primary biliary cirrhosis and in other liver diseases. Lancet 1973; 1 : 141921.

${ }^{12}$ Whittingham S, Mackay IR, Irwin J. Autoimmune hepatitis. Immunofluorescence reactions with cytoplasm of smooth muscle and glomerular cells. Lancet $1966 ; 1$ : 1333-5.

${ }^{13}$ Holborow EJ. Smooth-muscle autoantibodies, viral infections and malignant disease. Proc Roy Soc Med $1972 ; 65$ : 481-4.

${ }^{14}$ Linder E, Miettinen A, Kurki P, Alftan O. Liverspecific bile canalicular antibodies (letter). Lancet $1974 ; 2: 1275$.

${ }^{15}$ Klöppel F, Seifert G, Lindner H, Dammermann R, Sack HJ, Berg PA. Histopathological features in mixed types of chronic aggressive hepatitis and primary biliary cirrhosis. Correlations of liver histology with mitochondrial antibodies of different specificity. Virchows Arch A Path Anat Histol 1977; 373: 143-60.

${ }^{16}$ Bottazzo GF, Florin-Christensen A, Fairfax A, Swana G, Doniach D, Gröschel-Stewart U. Classification of smooth muscle autoantibodies detected by immunofluorescence. J Clin Pathol 1976; 29: 403-10.

${ }^{17}$ Kurki P, Linder E, Miettinen A, Alfthan O. Smooth muscle antibodies of actin and 'non-actin' specificity. Clin Immunol Immunopathol 1978; 9: 443-53.

${ }^{18}$ Gabbiani G, Ryan GB, Lamelin J-P, et al. Human smooth muscle autoantibody. Its identification as antiactin antibody and a study of its binding to "nonmuscular' cells. Am J Pathol 1973; 72: 473-88.

${ }^{19}$ Lidman K, Biberfeld G, Fargraeus A, et al. Anti-actin specificity of human smooth muscle antibodies in chronic active hepatitis. Clin Exp Immunol 1976; 24: 266-72.

${ }^{20}$ Kurki P. Determination of anti-actin antibodies by a solid phase immunoenzymatic assay and by indirect immunofluorescence technique. Clin Immunol Immunopathol 1978; 11 : 328-38.

${ }^{21}$ De Groote J, Desmet VJ, Gedigk P, et al. A classification of chronic hepatitis. Lancet 1968; 2: 626-8.

${ }^{22}$ Salaspuro MP, Sipponen P, Ikkala E, et al. Clinical correlations and significance of orcein positivity in chronic active hepatitis and primary biliary cirrhosis. Ann Clin Res 1976; 8: 206-15.

${ }^{23}$ Schalm SW, Ammon HV, Summerskill WHJ. Failure of customary treatment in chronic active liver disease: causes and management. Ann Clin Res 1976; 8: 221-7.

${ }^{24}$ Sherlock S, Scheuer PJ. The presentation and diagnosis of 100 patients with primary biliary cirrhosis. $N$ Engl J Med 1973; 289: 674-8.

${ }^{25}$ Kurki P, Linder E, Miettinen A, Alfthan O, Heikkinen A, Pasternack A. Tissue antibodies in malignant and benign urogenital disease. Int J Cancer 1977; 19: 332-6.

${ }^{26}$ Wachstein M, Meisel E. Histochemistry of hepatic phosphatases of a physiologic $\mathrm{pH}$; with special reference to the demonstration of bile canaliculi. Am J Clin Pathol 1957; 27: 13-23.

${ }^{27}$ Lidman K. Clinical diagnosis in patients with smooth muscle antibodies. A study of a one year material. Acta Med Scand 1976; 200: 403-7.

${ }^{28}$ Ladefoged K, Andersen P, Jørgensen J. Autoantibodies and serum immunoglobulins in chronic liver diseases. Acta Med Scand 1979; 205: 103-9.

${ }^{29}$ Pisi E, Marchesini G, Zauli D, Bianchi FB. Smooth muscle antibody in chronic hepatitis. In: Gentilini P, ed Chronic hepatitis, Int Symp Montecatini 1975. Basel ; Karger, 1976; 107-13.

${ }^{30}$ Diederichsen H, Møller-Nielsen P, Linde NC. Antikörper gegen Gallencanaliculi. Probleme des Nachweises und klinische Bedeutung. Z Gastroenterol 1975; 13: 271-7.

${ }^{31}$ Diederichsen H, Riisom K, Andersen I. Peripheral immunofluorescence of hepatocytes. Relation to smooth muscle antibodies and bile canaliculi. Acta Path Microbiol Scand Sect A 1977; 85: 399-404.

${ }^{32}$ Biberfeld G, Sterner G. Smooth muscle antibodies in Mycoplasma pneumoniae infection. Clin Exp Immunol 1976; 24: 287-91.

${ }^{33}$ Lamelin JP, Williams EH, Souissi T, De-Thé G, Gabbiani G. Smooth muscle antibody in Burkitt's lymphoma and nasopharyngeal carcinoma. Clin Exp Immunol 1977; 28: 157-62.

${ }^{34}$ Lidman K. Smooth muscle antibodies in chronic active hepatitis, Specificity and diagnostic value. Thesis: Stockholm, 1976.

${ }^{35}$ Trenchev P. Antigenicity of janin, a new protein from smooth muscle. Clin Exp Immunol 1976; 26: 267-72.

${ }^{36}$ Dietrichson $\mathrm{O}$, Christoffersen $\mathrm{P}$. The prognosis of chronic aggressive hepatitis. A clinical and morpho- 
logical follow-up study. Scand J Gastroenterol 1977; 12: 289-95.

${ }^{37}$ Salaspuro M, Sipponen P. Demonstration of an intracellular copper-binding protein by orcein staining in long-standing cholestatic liver diseases. Gut 1976; 17: 787-90.
${ }^{38}$ Nielsen JO. Clinical course and prognosis of acute hepatitis. Ann Clin Res 1976; 8: 151-7.

${ }^{30}$ Niermeijer P, Gips CH, Verkek S, Snijder JAM. Immunoglobulin classes of smooth muscle antibody in the course of acute hepatitis B: prognostic significance. Acta Hepato-Gastroenterol 1978; 25: 444-9. 